\title{
Heat pumps in the future
}

\author{
Tímea Gresz ${ }^{1}$ Dávid Faragó $^{1}$, and Péter Bencs ${ }^{1 *}$ \\ ${ }^{1}$ Institute of Energy Engineering and Chemical Machinery, Department of Fluid and Heat \\ Engineering, University of Miskolc, H-3515 Miskolc, Hungary
}

\begin{abstract}
It has been discovered long ago that geothermal energy can be used to substitute various types of fossil fuels. Heat pumps are devices that can transfer the earth's thermal energy from a cooler to a warmer space. Their deployment would not only benefit large companies but could even reduce the everyday costs of individuals. Among their many advantages, possibly the most important one is that it is environmentally friendly. Their power demand can ideally be satisfied using other renewable energy sources. In this article, the current situation of heat pumps and geothermal energy in Hungary, Sweden and Germany are examined including incentives and grants. Afterwards, the current situation and operation of hybrid systems in Sweden and Egypt are studied.
\end{abstract}

\section{Introduction}

It is a well-known fact that fossil fuels - such as oil, natural gas, etc. - are finite and are becoming scarce, but the most serious issue is the inherent $\mathrm{CO}_{2}$ emissions involved with them. Previously undiscovered oil and gas deposits are being found every so often, and there are also cases where extraction used to not be economically viable, but with increasing prices and the availability of more advanced technology, nowadays it is.

Heat pumps can be used to provide an alternative to fossil fuels for heating and providing hot water. They are environmentally friendly and can produce heat relatively quickly and cheaply. Heat pumps use electricity to produce hot water and are also suitable for either heating or cooling. Their main advantages are that they do not require a lot of space and are suitable to be operated at high performance [1].

The principle of the heat pump was first conceived by James Joule and William Thomson in 1852. Peter Ritter von Rittinger implemented the world's first industrial heat pump based on Carnot's thermodynamic writings. The first building that was continuously heated solely by a heat pump was instituted in 1938 in Zürich, the heat source being the water of the Limmat river.

In 1948, László Heller achieved a technological breakthrough with the development of the compressor heat pump. For example, the heat pump of the Bundestag building was designed in such a way that it could provide heating during the heating season, and cooling in summer.

\footnotetext{
* Corresponding author: arambp@uni-miskolc.hu
} 
The energy demand of heat pump systems can be provided by renewable energy sources such as solar, wind, hydroelectric, biomass and geothermal [3].

Table 1. Average soil temperatures in Hungary

\begin{tabular}{|c|c|}
\hline Depth & Temperature \\
\hline $500 \mathrm{~m}$ & $35-40{ }^{\circ} \mathrm{C}$ \\
\hline $1000 \mathrm{~m}$ & $55-60{ }^{\circ} \mathrm{C}$ \\
\hline $2000 \mathrm{~m}$ & $100-110^{\circ} \mathrm{C}$ \\
\hline
\end{tabular}

Even though most of the major geothermal energy sources are usually found around volcanically active areas, the geothermal potential of Hungary is significant. On average, soil temperatures increase by about $45^{\circ} \mathrm{C} / \mathrm{km}$ with depth, detailed in Table 1 .

In warmer areas, this gradient can be of much higher values (as high as $120-130{ }^{\circ} \mathrm{C} / \mathrm{km}$ ). More than $70 \%$ of the territory of Hungary has thermal water deposits with a minimum temperature of $30^{\circ} \mathrm{C}$ [4]. Soil temperature distributions at different depths are shown in Figure 1. Dark blue indicates $40{ }^{\circ} \mathrm{C}$, yellow indicates $110^{\circ} \mathrm{C}$, and brown indicates the soil temperature of $150^{\circ} \mathrm{C}$.
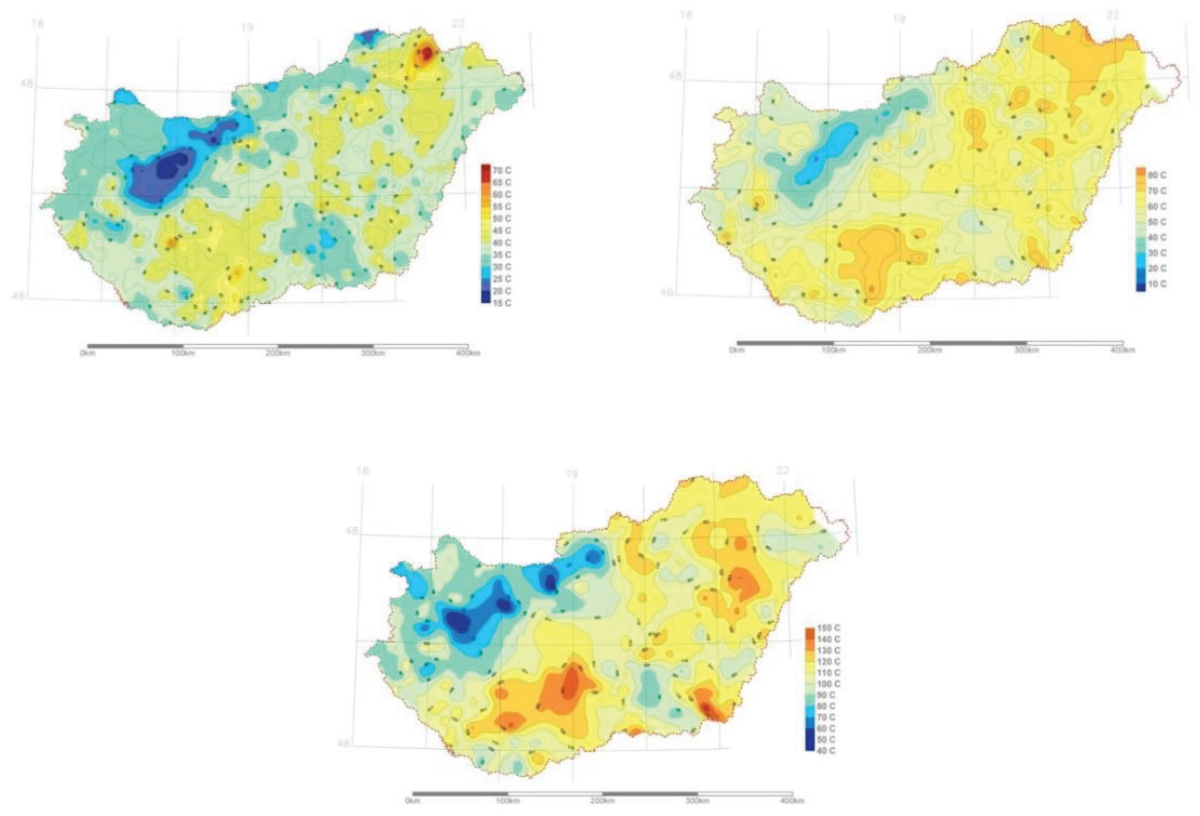

Fig. 1. Temperature distribution of Hungary at 500, 1000, $2000 \mathrm{~m}$ depth [4]

\section{Heat pumps and their applications}

The primary heat source of modern heat pumps is the geothermal heat of the ground. From there, heat is extracted by a horizontal closed loop field of pipes or vertical probes in boreholes. The principle of operation is practically the same as that of a refrigerator but in reverse. The refrigerant is heated in a piping system, which is located 1.5-2 meters below the ground to avoid any major temperature change due to external effects. This heat is absorbed by the circulating refrigerant through the heat exchanger on one side. The temperature of the 
fluid further increases while it flows up the narrow-section tube, then the heat is released on the other side [2].

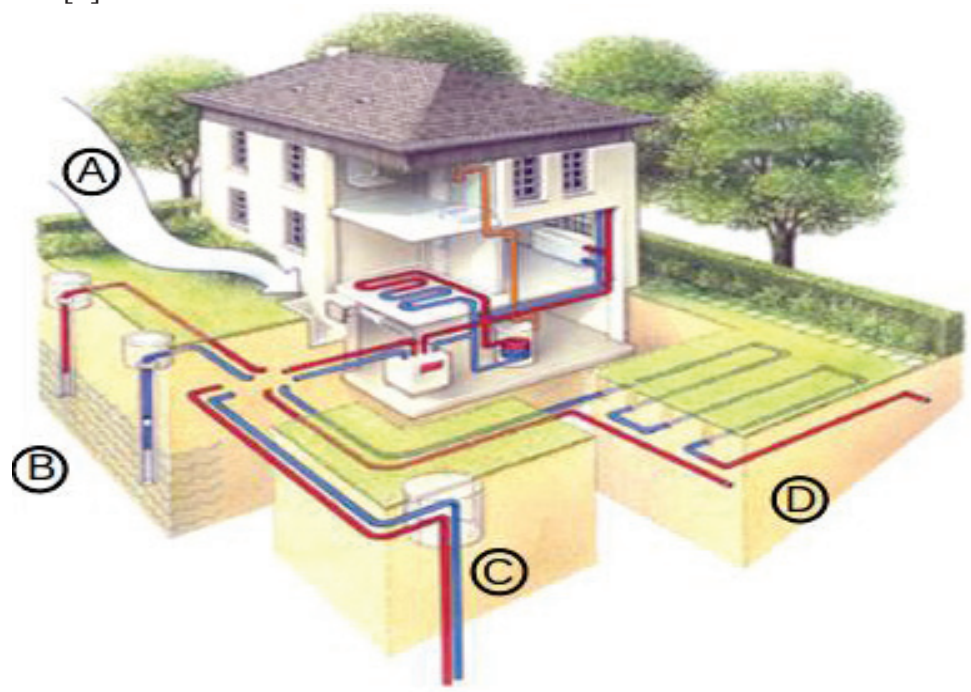

Fig. 2. Types of heat pumps [7]

The main types of heat pumps, illustrated in Figure 2: [2]

- $\quad$ air-water type (A),

- water-water type (B),

- ground-water probe (C),

- ground-water collector (D).

One of the most popular types is the vertical arrangement of the ground source heat pumps for several reasons. It has the best efficiency, it is environmentally friendly, there is no combustion product and no need for people to take care of ash and flue gas disposal, no need to buy fuel, no need to carry it from the storage to the boiler.

"COP (Coefficient of Performance) is the ratio of the heating capacity of a heat pump to its effective power input." [3].

Water-water heat pumps possess the highest COP of which the large body water is the highest (COP: 4-6), closely followed by groundwater-based heat pumps (COP: 3-5). Airwater type heat pumps have a COP of $2-3$ if the air temperature is above $0{ }^{\circ} \mathrm{C}$, and $1-2$ if subzero. The coefficient of performance of an air-air type heat exchanger falls between 1 and 3 , but this largely depends on the ambient temperature [2].

Heat pumps, besides heating and cooling, can also be used to power household appliances, such as washers and dryers, where a heat pump can perform the drying function. Implementing such methods, the energy efficiency of the household can be greatly improved, as the most energy-intensive household appliances are those that use water during their operation [5].

They can be used for both heating and heat retention, not only in households but also in fish farming systems. An air-water heat pump was used to heat and hold the water temperature in a fish tank, with a COP not falling below 4.31. This solution is not only environmentally friendly but also cost-effective as it leads to a much higher reproductive rate of fish [6].

The possible functions of heat pumps are not limited to heating or hot water production, they can be used for cooling purposes as well. This can be achieved in two different ways, 
active or passive cooling. Passive cooling is one of the cheapest ways to lower the temperature inside a building. However, when the summer heatwave is raging endlessly, passive cooling is no longer sufficient. In active cooling systems, a combined buffer tank cannot be used, so a separate tank is needed for cooling-heating, and a separate tank for hot water production. Cooling with a heat pump is $67-75 \%$ cheaper compared to cooling with an air conditioner. On contrary, cooling with a heat pump requires three times as much energy as heating [7].

\section{Geothermal energy in Europe}

Europe aims to become the world's first climate-neutral continent by 2050. In 2018, 21.1\% of the energy used for cooling and heating was provided by renewable sources (Table 2), an increase of almost $10 \%$ compared to 2004 [8].

Table 2. Rate of energy produced from renewable energy sources for cooling and heating [\%] [8]

\begin{tabular}{|c|c|c|c|c|c|c|c|c|}
\hline & $\mathbf{2 0 0 4}$ & $\mathbf{2 0 0 6}$ & $\mathbf{2 0 0 8}$ & $\mathbf{2 0 1 0}$ & $\mathbf{2 0 1 2}$ & $\mathbf{2 0 1 4}$ & $\mathbf{2 0 1 6}$ & $\mathbf{2 0 1 8}$ \\
\hline Germany & 7.2 & 8.4 & 10.3 & 12.1 & 13.4 & 13.4 & 13.0 & 13.6 \\
\hline Sweden & 46.6 & 54.2 & 57.6 & 59.1 & 62.7 & 64.6 & 65.5 & 65.4 \\
\hline Hungary & 6.4 & 11.4 & 12.0 & 18.1 & 23.3 & 21.3 & 21.0 & 18.1 \\
\hline
\end{tabular}

In Sweden, the temperature gradient is $15-20{ }^{\circ} \mathrm{C} / \mathrm{km}$, clearly much lower than in Hungary, yet heat pumps are much more common. Sweden is at the forefront of geothermal energy usage within Europe, in fact even surpasses the USA in this regard. The proliferation of heat pumps, with $30 \%$ of single-family homes using them from as early as 2008, is largely due to state subsidies and a system of regional, interest-free loans [4].

Figure 3 shows the distribution of the geothermal heat map of Europe. It can be seen that the model temperature is much lower in Sweden. Hungary has extraordinarily high values, but Germany and France also have values of around $120-150{ }^{\circ} \mathrm{C}$ at a depth of $5 \mathrm{~km}$.

Geothermal heat pumps are becoming extremely widespread in Germany as well. In this case, it is mainly due to the Renewable Energy Act, which set a very favorable price for electricity from renewable energy sources [4]. In Germany, the BAFA and MAP deal with energy upgrading of existing buildings. For new buildings, only innovative and efficient heat pump systems are financed. From 1 . January $2020,35 \%$ of the costs for the construction of heat pumps and related environmental measures will be covered, which can be further increased to up to $45 \%$ if oil heaters are replaced [12]. Financial support will also be provided if the heat pump is only installed for heating and the hot water is produced from nonrenewable energy sources. The funding has also been extended to hybrid heating systems. Applications are open to individuals, municipalities, corporations, non-profit organizations, etc. Air-air heat pumps, self-built or second-hand systems are not eligible for financial support [13]. 


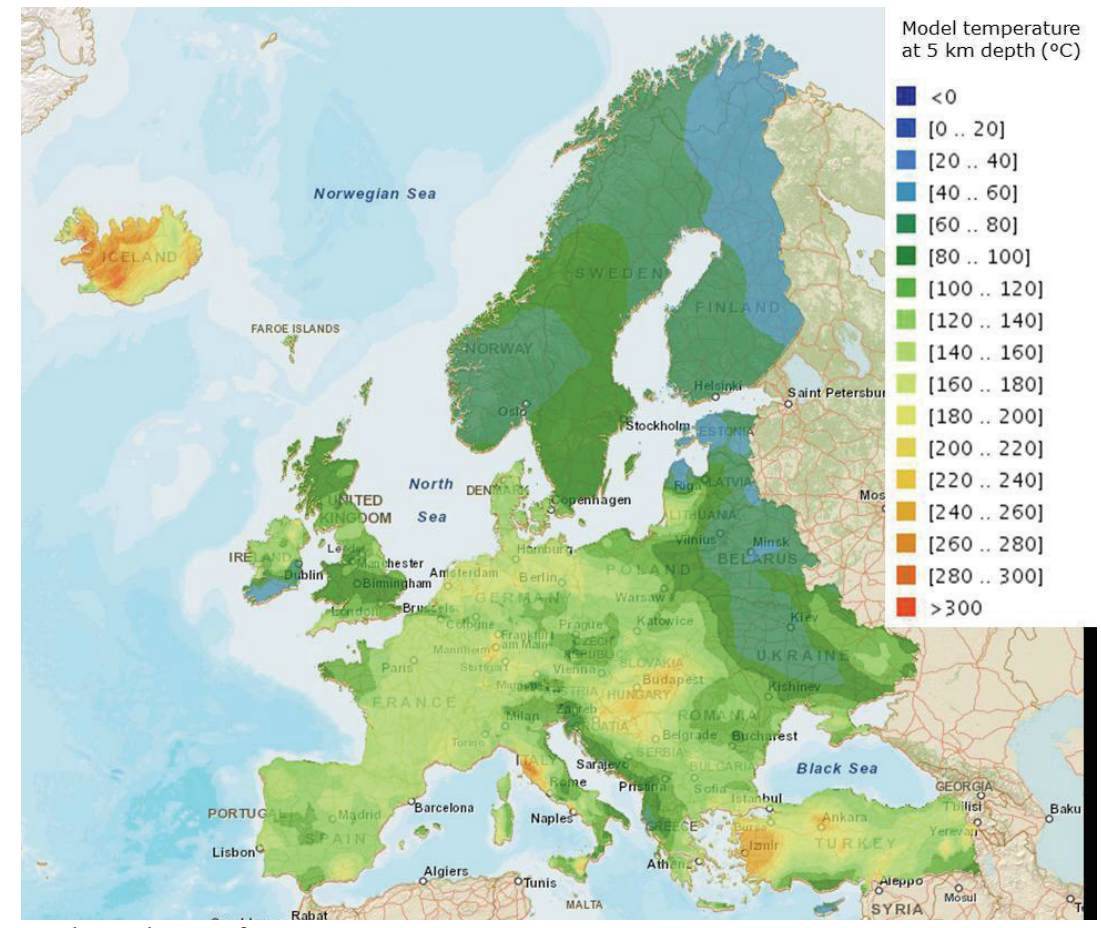

Fig. 3. Geothermal map of Europe

In Hungary, the first geothermal power plant to produce electricity was established in Tura (Figure 4). The plant runs Organic Rankine Cycle (ORC) technology to generate 2.7 MW of electricity. Construction of the plant started in 2017 and the first part was commissioned in 2018 [15].

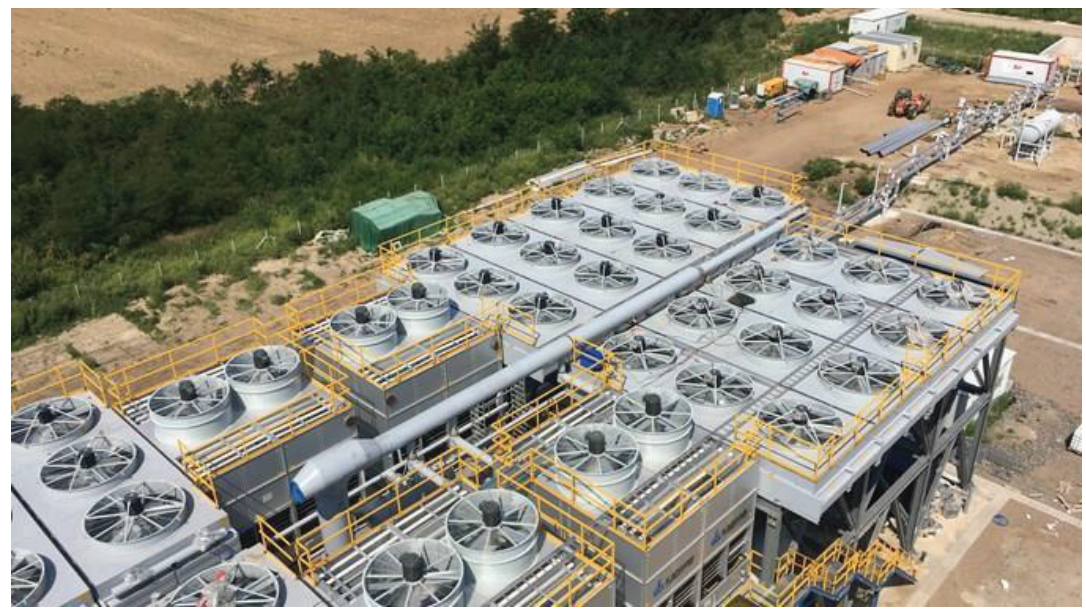

Fig. 4. Geothermal plant in Tura, Hungary [15]

One of the most important reasons that heat pumps are not as widespread in Hungary as in other countries is probably that tenders are often available for only a month. A more predictable and more general incentive, offering at least $30 \%$ subsidies, would be 
recommended to encourage the public to invest in heat pipe systems. Experiences show that such high grants are only necessary for about 5-10 years, when heat pump systems are introduced to the market to help their early spread [9]. After this period, the subsidy rate could be decreased to around $10 \%$. In addition to domestic or EU subsidies, it would also be important to reduce the price of electric power for heat pumps during the heating season. This approach has already been implemented by Germany, generally making the payback period of heat pump investments significantly shorter [10].

There used to be a well-functioning tendering system between 2000-2005; it was designed to promote the comprehensive use of renewable energy sources. After that, only the Environmental Protection and Infrastructure Operational Programme offered tenders, but these were not open to the public as they were available only for large-scale projects. This was followed by the Environment and Energy Operational Programme, which ran between 2009-2015, but once again, tender intervals were not predictable [11]. A major drawback was that the region of Central Hungary was not eligible for the Environmental Protection and Infrastructure Operational Programme fundings.

To install a heat pump system, a water permit is required, which must be obtained from the General Directorate of Water Management, where an application must first be submitted. There are, of course, costs involved in the procedure, depending on:

- water usage, water quantity,

- investment cost, etc.

The costs of the authorities to be paid by the customer:

- Directorate of Plant Protection and Soil Conservation

- Forestry Directorate

- Ministry of Agriculture, Department of Land Administration and Geoinformation

- National Directorate General for Disaster Management

- National Transport Authority

The payback period for ground source heat pumps in Hungary are [14]:

a) For an existing building with a heated volume of $682 \mathrm{~m}^{3}$ :

- without tender: 8.1 years payback period,

- with tender: reduced to 5.8 years.

b) For a new building where it could be used for both heating and cooling:

- without tender: 4.2 years,

- with tender: reduced to 2.2 years.

There are similar payback periods in Germany, without tender it takes 7-10 years, but with the BAFA tender, the payback period is much shorter.

Today's new hybrid heat pump systems use renewable energy sources (such as solar or geothermal energy) to produce heating or domestic hot water. This new system has been developed and pioneered in Sweden, and a test plant was completed by 2015. The new system consists of a hybrid solar panel, a ground source heat pump, and a borehole thermal energy storage. The hybrid solar panel differs from conventional solar panels in that the PV panels circulate a cooling medium, such as water or air. During the operation of the system, the water is heated to about $10{ }^{\circ} \mathrm{C}$ on the PV panel and then fed to the cold-side ground-source heat pump and used as a heat source. If excess heat is generated, it is fed into boreholes where the ground absorbs the unused heat energy. Boreholes contribute greatly to increasing the efficiency of heat pumps. In boreholes, we can store the excess energy produced during hot summer months and use it in the colder seasons as required [16]. 
In recent years, a new cooling system for photovoltaic panels has been tested in the Port Said area of Egypt. A ground-air heat exchanger is used for cooling. With this method, the cooling of the solar panel is solved, and its performance is improved at the same time. The $P V_{R}$ notation used in Table 3 can be taken as a reference, while the $P V_{C}$ shows the details of the hybrid system. The costs are given in US dollars. It can be observed that when coupled with a heat pump, the system does not represent a very large additional cost, namely an extra $\$ 150[17]$.

For a conventional solar PV system, the levelized cost of energy (LCOE) is 0.87 (US $\$ / \mathrm{kWh}$ ), while for a hybrid system the LCOE is 0.76 (US $\$ / \mathrm{kWh}$ ). Additionally, the relative energy cost is reduced by $12 \%$ and allows the generation of $36 \mathrm{kWh}$ of electricity and the avoidance of $13986 \mathrm{~g}$ of $\mathrm{CO}_{2}$ emissions during the summer season [17].

Table 3. Cost distribution of the hybrid system and solar panel [17]

\begin{tabular}{|c|c|c|}
\hline Spare parts & PVR (\$) & PVC (\$) \\
\hline PV panels & 300 & 300 \\
\hline Galvanized steel rack and structures & 40 & 40 \\
\hline Battery & 225 & 225 \\
\hline Solar charge controller (MPPT) & 112 & 112 \\
\hline Insulation & - & 10 \\
\hline Piping and regulators & - & 15 \\
\hline Air blower & - & 35 \\
\hline Ground-air heat exchanger & - & 90 \\
\hline
\end{tabular}

\section{Conclusion}

Renewable energy sources can be of great assistance throughout the course of fossil fuel phase-out. Today, mainly owing to major incentives, solar energy has the largest share among various renewable energy sources in Hungary.

The heat pumps presented in this paper have already established themselves in Sweden and Germany. However, even though geothermal energy would be much more affordable in most areas of Hungary, there are still very few examples of established geothermal plants, and heat pumps are far from being widespread. The main reason behind this insensitivity towards heat pumps is the lack of incentives. Were a public domestic tender system available, the various heat pump systems would begin proliferating.

Heat pumps can be powered by renewable energy sources (such as solar or geothermal energy), making their operation much more economical and reducing inherent $\mathrm{CO}_{2}$ emissions at the same time. Recently there has been a growing tendency to research hybrid heat pump systems, and they are expected to become more common, since they are only slightly more expensive than a simple solar system, but much more versatile.

This research was supported by the European Union and the Hungarian State, co-financed by the European Regional Development Fund in the framework of the GINOP-2.3.4-15-2016-00004 project, aimed to promote the cooperation between higher education and the industry. 


\section{References}

1. G. Hajdú, A Höszivattyú a Jövő Energiaforrása a Nap és Föld Hőjének Hasznosítása. | Magyar Kert és Energia Klaszter (2010).

2. B. Darabos, Mi az a Höszivattyú? | Bio-Solar-Haz (2008).

3. F. Komlós, Z. Fodor, Z. Kapros, and L. Vaszil, Hőszivattyúzás | Csináljuk Jól! Energiahatékonysági Sorozat (2007).

4. J. Mádlné Dr. Szőnyi, A Geotermikus Energiahasznosítás Nemzetközi és Hazai Helyzete, Jövőbeni Lehetőségei Magyarországon (2008).

5. J. Cranston, A. Askalany, and G. Santori, Efficient Drying in Washer Dryers by Combining Sorption and Heat Pumping, Energy 183, 683 (2019).

6. G. Géczi, P. Korzenszky, T. Szabó, L. Bense, and B. Urbányi, Levegő-Víz Hőszivattyú Alkalmazásának Lehetősége az Intenzív Recirkulációs Haltenyésztésben, AWETH 9, 139 (2013).

7. Quadronet, Hőszivattyú az Igazi Rezsistop Gázkazán Helyett. Füt, Hüt Gazdaságosan (2018).

8. E. Eurostat, Share of Energy from Renewable Sources for Heating and Cooling, 20042018 (2020).

9. Z. Kalocsai, Fellendülés Előtt a Hőszivattyú Piac - Magyar Hőszivattyú Szövetség (2010).

10. E. Energiainfo, Drága, De Megtérül a Geotermikus Energia, Energiainfo (2009).

11. NKFIH, Széchenyi Terv Plusz, Magyarországa Kormánya (2021).

12. L. O'CONNOR, Geothermal Energy - New Report Analyses the Sector - European Commission (2016).

13. S. Dr. Björn, Bundesverband Wärmepumpe, BEG Förderprogramm (2020).

14. F. Komlós and Z. Fodor, Nem Szívás! Érvek, Számítások a Hőszivattyús Rendszer Mellett., Mérnök Újság 18, 24 (2011).

15. Mannvit, Tura Geotermikus Erömü (2018).

16. W. Steel, Novel Hybrid Solar PV-Geothermal Energy System Piloted in Sweden, Renewable Energy World (2019).

17. N.A.S. Elminshawy, A.M.I. Mohamed, K. Morad, Y. Elhenawy, and A.A. Alrobaian: Performance of PV panel coupled with geothermal air-cooling system subjected to hot climatic, Applied Thermal Engineering 148, 1 (2019). 